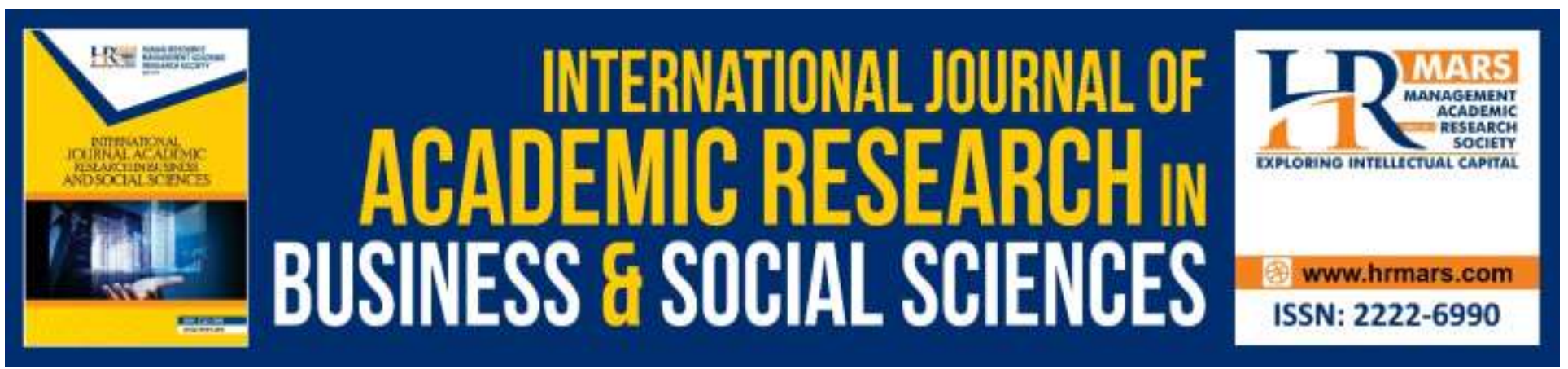

\title{
Selected Model of Instructions for Physical Education
}

\author{
Noraliza Minhat, Norkhalid Salimin, Sanmuga Nathan
}

To Link this Article: http://dx.doi.org/10.6007/IJARBSS/v9-i6/6066

DOI: $10.6007 /$ IJARBSS/v9-i6/6066

Received: 18 April 2019, Revised: 19 May 2019, Accepted: 07 June 2019

Published Online: 29 June 2019

In-Text Citation: (Minhat, Salimin, \& Nathan, 2019)

To Cite this Article: Minhat, N., Salimin, N., \& Nathan, S. (2019). Selected Model of Instructions for Physical Education. International Journal of Academic Research in Business and Social Sciences, 9(6), 1053 - 1060.

Copyright: (c) 2019 The Author(s)

Published by Human Resource Management Academic Research Society (www.hrmars.com)

This article is published under the Creative Commons Attribution (CC BY 4.0) license. Anyone may reproduce, distribute, translate and create derivative works of this article (for both commercial and non-commercial purposes), subject to full attribution to the original publication and authors. The full terms of this license may be seen

at: http://creativecommons.org/licences/by/4.0/legalcode

Vol. 9, No. 6, 2019, Pg. $1053-1060$

http://hrmars.com/index.php/pages/detail/IJARBSS

JOURNAL HOMEPAGE

Full Terms \& Conditions of access and use can be found at http://hrmars.com/index.php/pages/detail/publication-ethics 


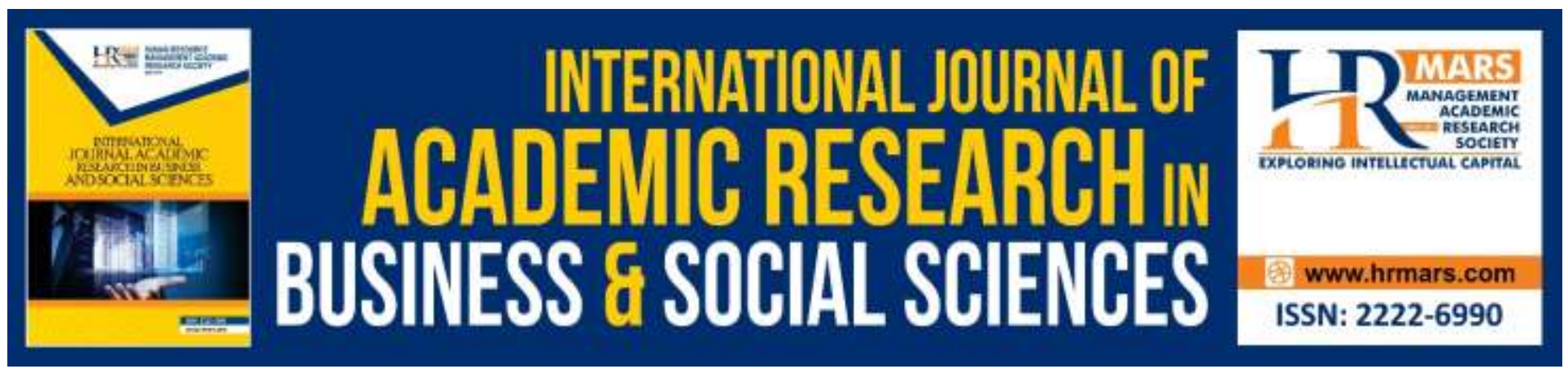

\title{
Selected Model of Instructions for Physical Education
}

\author{
Noraliza Minhat, Norkhalid Salimin, Sanmuga Nathan \\ Sultan Idris Education University, Malaysia
}

\begin{abstract}
This paper deals with the instruction models in Physical Education, Teaching Games for Understanding (TGfU) and Sport Education Model as possible options in the instruction of Physical Education games. Each instruction has certain features and appropriate features can be combined to form Hybrid Teaching Games for Understanding - Sport Education Model. This hybrid model can be used as an option for teaching Physical Education in the invasion games, net and wall games, striking and fielding games and target games.
\end{abstract}

Keywords: Teaching Games for Understanding (TGfU), Sport Education Model, Hybrid of Model Teaching, Physical Education, Instruction Model

\section{Introduction}

The concept of contemporary education encourages individuals to acquire new knowledge, think critically, use and develop cognitive skills as scientific thinking and problem solving (Bilgin \& Dalkıran, 2017). In order to achieve the concept of education, the instruction in Physical Education needs to be diversified in achieving teaching and learning objectives. Pedagogy or instruction in game teaching cannot be separated from the development of Physical Education (Nathan, 2014). Pedagogy in global Physical Education has gone through five stages of development : the first one is the Physical Education Method of the 1950s, the second one is the Instructional Strategies of the 1960s, the third one is Mosston's Spectrum of Teaching Styles in the 1960s, the fourth one is Effective Teaching Styles of the 1970s, and lastly, Instructional Models from 1980s to the present (Metzler, 2011). According to Metzler (2011), there are eight types of models designed to teach Physical Education which are Direct Instruction, Inquiry Teaching, Sport Education Model, Peer Teaching, Personalized Systems for Instruction, Teaching for Responsibility, Cooperative Learning and Teaching Games for Understanding (TGfU ). The development of Physical Education (PE) pedagogy has a positive impact on the teaching and learning of PE including games from around the world. The purpose of this article is to find effective instruction for improving psychomotor, cognitive and affective domains in the game situations. Instruction models for choice in innovation management for PE are TGfU and Sport Education Model.

Teaching Games for Understanding

Teaching Games for Understanding (TGfU) was founded by Bunker and Thorpe in 1982 (Kirk \& 
MacPhail, 2002). In the current study, the TGfU Model is utilised as it is a student-centered instruction model and the focus of today's instruction should aim more on the instruction process that effectively involves the students (Nathan, 2014). As a student-focused approach, it aims to provide students with an understanding of the technical and tactical skills that have achieved success in various types of games as well as creating ongoing involvement (Mandigo \& Holt, 2004). The original model proposed by Bunker \& Thorpe (1982) comprised six steps in game instruction namely game, game appreciation, tactical awareness, making appropriate decisions, skill execution and performance. In TgfU Instruction, there are four pedagogical principles: sampling, representation, exaggeration and tactical complexity suggested by Bunker and Thorpe (1992) (Griffin, Brooker, \& Patton, 2005).

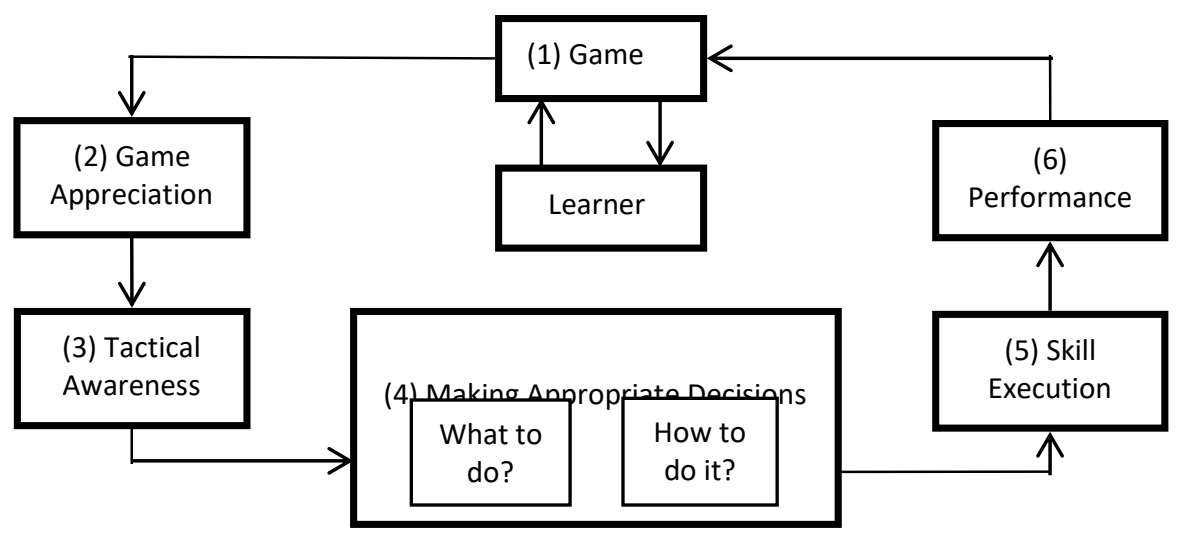

Figure 1. Teaching Games for Understanding (TGfU)

The original TGfU model proposed by Bunker \& Thorpe (1982), recommends six steps in the game instructions as in Figure 1:

i. Game - Students' understanding of the game form is a game in the form of real game modifications that have specific objectives and understanding of concepts, skills and abilities related to a game category.

ii. Game Appreciation - Pupil generates rewards for rules, skills and strategies that affect the game.

iii. Tactical Awareness - participating in real game situations will open up opportunities to think about tactical decisions such as open space, space closure, decision-making skills in the game, tactical attack and tactical survival.

iv. Making Appropriate Decision - Students understand how to make the right decisions in the game situations by answering the question of what tactical games in the game are needed and how to conduct tactical games that have been planned based on game appreciation and tactical awareness.

v. Skill Execution - Pupils perform skills in the game correctly and are able to decide on the selection of skills in the game and improve the skill level from low to high.

vi. Performance - the Game Performance Assessment Instrument (GPAI) by Mitchell, Stephen A. Oslin, Judith L. Griffin (2013) has been modified in the real game to ascertain the level of skill 
implementation, tactical decisions and decision making skills. The strengthening aspect will be given to the poor students' learning achievement and to monitor the effect of the instructions used to make improvements. Affective aspects are assessed through an Affective Assessment Instrument to look at the aspects of sports that are focused. The student's learning achievement is kept as a record to determine the improvement of student learning.

\section{Sport Education Model}

The Sport Education Model was developed and introduced by Daryl Siedentop in 1994. The Sport Education Model is one of the instruction model designs produced for the Physical Education program at the primary, secondary and tertiary levels that focuses on students. The three main aims that guide development in the Sport Education Model are to produce competent, literate and enthusiastic students (Siedentop, 1994). According to Siedentop (1994), Sport Education Model has six main features: seasons, affiliation, formal competition, culminating event, record keeping and festivities as in Figure 2:

i. Seasons - The "unit" in sport education is often two to three times longer than the typical physical education units.

ii. Affiliation - Students become members of teams at the start of a season and retain their team affiliation throughout the season. Students plan, practise and compete as a team. All students are given a role in learning to become captains, coaches, team managers, trainers, tool managers, statistics, referees, scorers, public officials and sports board members.

iii. Formal competition - Sport seasons are typically defined by a schedule of formal competition interspersed with practice sessions. The affiliation and formal competition features combine to provide the opportunity for planning and goal setting that create the context for pursuing important outcomes that have real meaning for students.

iv. Culminating event - It is in the nature of sport to find out who is the best sportsman for a particular season and for others to mark their progress in relationship to that outcome.

v. Record keeping - Records provide feedback for individuals and groups, help to define standards and are fundamental to defining goals and to define sport traditions .

vi. Festivities - Sport competitions are occasions for festivity. In sport education, teachers and students work together to create a continual festival that celebrates improvement, trying hard, and playing fairly 


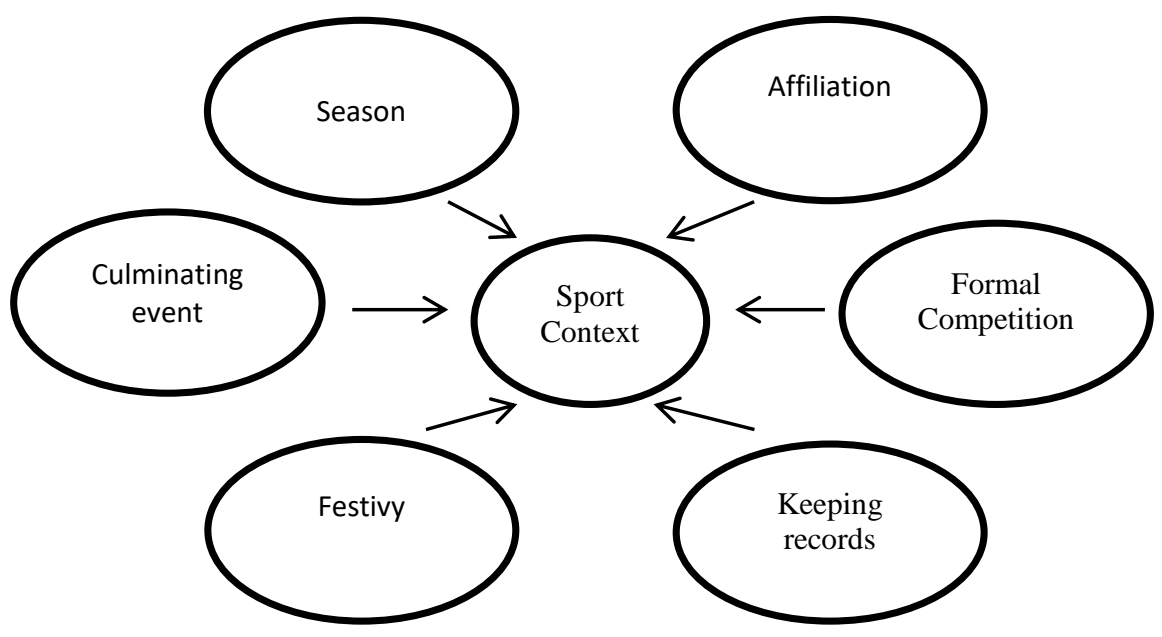

Figure 2. Sport Education Model

Siedentop (1994) has outlined the objectives to be achieved by students attending the teaching and teaching sessions of Sport Education Model (Siedentop, Hastie, \& Hans Van Der Mas, 2011).

i. Develop specialized skills and fitness for a particular sport.

ii. Appreciate and be able to implement game strategies in sports.

iii. Participate at a level appropriate to their development stage.

iv. Share in planning and administration based on sports experience.

v. Forming responsible leadership.

vi. Work effectively in groups towards the same goal.

vii. Appreciate rituals and conventions that give particular sports a unique meaning.

viii. Developing the ability to make decisions about sports issues.

ix. Build and use knowledge of judges, judges, referee, and training.

x. Make a voluntary decision to engage in sport after school.

\section{Hybrid Teaching Games for Understanding - Sport Education Model}

The components contained in TGfU and Sport Education Model are processed into Hybrid Teaching Games for Understanding - Sport Education Model. Metzler stated that there are eight instructional models designed as an alternative to teachers in PE teaching. Among them are Teaching Games for Understanding (TGfU) and Sports Education Model (Metzler, 2011). Teachers using TGfU instruction make cognitive domains interesting and pupils learn the tactical aspects of the game through small games, real games and modified games according to the student's progress (Harvey \& Jarrett, 2014). Although cognitive domains are important through the design of teacher skills, technical skills are simultaneously developed tactically in context according to the complex pedagogical and tactical modification principles (Werner, Thorpe, \& Bunker, 1996). The Sport Education Model is aimed at producing students who are competent, literate and passionate about the game. According to Kirk, (2013), the Sport Education Model is a model based on well-established and evidence-based pedagogy models where teachers focus on student-centered learning through a cooperative and 
controversial pedagogy based on six features of the Sport Education Model. Therefore combining several features in the Sport Education Model to TGfU enables a positive impact in improving the psychomotor domain, cognitive and affective student

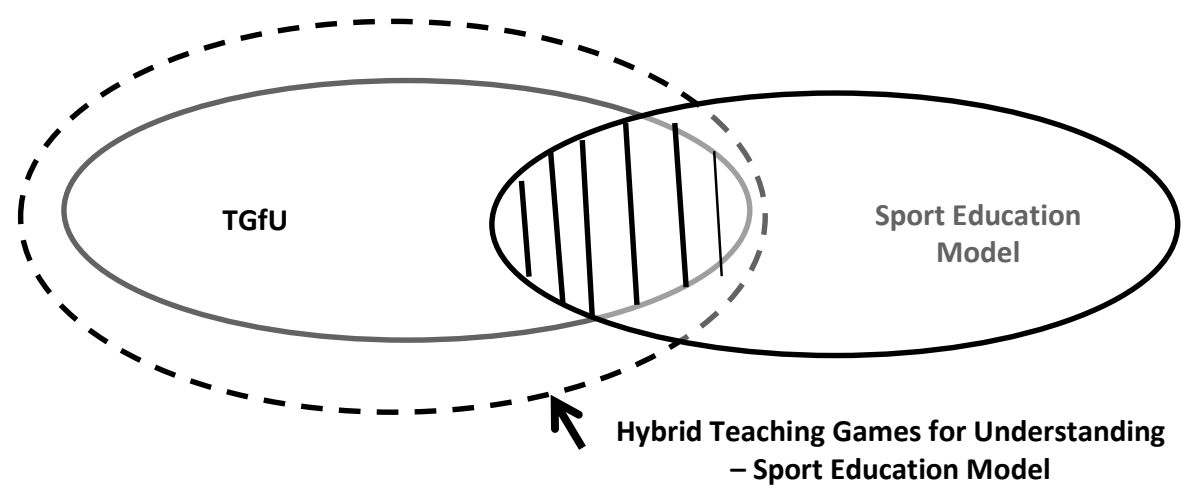

Figure 3. Hybrid Teaching Games for Understanding - Sport Education Model

\section{Consequences of Teaching Games for Understanding (Tgfu) and Sport Education Model}

This TGFU instruction model is more focused on the overall understanding of each game. Pupils can understand a particular principle or concept in a particular game indirectly emphasizing the increased levels of physical activity. TGfU indicated increases in tactical decision making, skill execution, game performance, game involvement, game knowledge, enjoyment, perceived competence and the intention to continue practising (Morales-Belando \& Arias-Estero, 2017). Therefore, the PE class becomes the suitable place for having competition, motivation and fun.

The Sport Education Model encourages students to be team members. The participation of low-skilled pupils can improve their skills to a higher level and enable them to understand the right game knowledge in teaching (Pereira, Araújo, Farias, Bessa, \& Mesquita, 2016; Herrera, 2017). One of the main features of the Sports Education Model is the merger of the team which gives the roles to the students (Siedentop, 1998). The role given to students in team affiliation makes them more motivated to join teammates in activities without limiting participation even though they are lowskilled.

\section{Conclusion and Future Agenda}

The combination of the TGfU model and the Sport Education Model can be used in PE teaching via the teachers' creativity in teaching to achieve the objectives of the lesson while promoting the maximum involvement of students in the Physical Education class irrespective of their mastery in game skills. There is cognitive improvement in the decision making of opening space, closing space and selected skills in real game play. Their leadership qualities can be enhanced as a team by forming self-responsibility, in-person and ethical interactions in effective sports. Three features in the Sport Education Model, affiliation, formal competition and festivities are proposed to be included in TGfU to make a hybrid instruction model which is named as Hybrid Teaching Games for Understanding Sport Education Model (HTGFU - SEM). HTGfU - SEM is intended to be used in the study of various types of games in net and wall games categories, invasion games and striking and fielding games for 
INTERNATIONAL JOURNAL OF ACADEMIC RESEARCH IN BUSINESS AND SOCIAL SCIENCES

Vol. 9, No. 6, June, 2019, E-ISSN: 2222-6990 @ 2019 HRMARS

psychomotor, cognitive and affective domains. Therefore HTGfU - SEM can be chosen as one of the Physical Education approaches in the future.

\section{Corresponding Author}

Noraliza Minhat,

Faculty of Sport Science and Coaching,

Sultan Idris Education University,

Malaysia.

Email:nrlz_minhat@yahoo.com

\section{References}

Bilgin, N., \& Dalkıran, O. (2017). Examining Attitudes of Students Regarding the Sports Education Model and Direct Teaching Model. Journal of Education and Training Studies, 5(12). https://doi.org/10.11114/jets.v5i12.2718

Bunker, D., \& Thorpe, R. (1982). A model for the teaching of games in secondary schools. Bulletin of Physical Education, 18.

Griffin, L. L., Brooker, R., \& Patton, K. (2005). Working towards legitimacy: two decades of teaching games for understanding. Physical Education \& Sport Pedagogy, 10(3), 213-223. https://doi.org/10.1080/17408980500340703

Harvey, S., \& Jarrett, K. (2014). A review of the game-centred approaches to teaching and coaching literature since 2006. Physical Education and Sport Pedagogy, 19(3), 278-300. https://doi.org/10.1080/17408989.2012.754005

Herrera, H. (2017). A Review of Literature on the Benefits of Sport Education on Secondary Physical Education.

Kirk, D., \& MacPhail, A. (2002). Teaching games for understanding and situated learning: Rethinking the Bunker-Thorpe model. Journal of Teaching in Physical Education, 21, 177-192.

Kirk, David. (2013). Educational Value and Models-Based Practice in Physical Education Educational Value and Models-Based Practice in Physical Education. Educational Philosophy and Theory, 45(9), 873-986. https://doi.org/10.1080/00131857.2013.785352

Mandigo, J. L., \& Holt, N. L. (2004). Reading the game: Introducing the notion of gammes literacy. Physical and Health Educational Journal, 70(3), 4-10.

Metzler, M. (2011). Instructional Model for Physical Education (3rd ed.). Scottsdale,AZ: Holcomb Hathaway.

Minhat, N., Salimin, N., \& Nathan, S. (2019). Selected Model of Instructions for Physical Education. International Journal of Academic Research in Business and Social Sciences, 9(6), 774-781.

Mitchell, Stephen A. Oslin, Judith L. Griffin, L. L. (2013). Teaching Sport Concepts and Skills : A Tactical Games Approach for Ages 7 to 18 (3rd ed). Champaign, IL: Human Kinetics.

Morales-Belando, M. T., \& Arias-Estero, J. L. (2017). Influence of Teaching Games for Understanding on Game Performance, Knowledge, and Variables Related to Adherence in Youth Sailing. Journal of Teaching in Physical Education, 36(2), 209-219. https://doi.org/10.1123/jtpe.20160024 
Nathan, S. (2014). Instruksi Model Taktikal Permainan. PTS Akademia, Malaysia.

Pereira, J., Araújo, R., Farias, C., Bessa, C., \& Mesquita, I. (2016). Sport Education and Direct Instruction Units: Comparison of Student Knowledge Development in Athletics. Journal of Sports Science \& Medicine, 15(4), 569-577.

Siedentop, D. (1994). Sport Education: Quality PE Through Positive Sports Experiences. Human Kinetics Publishers.

Siedentop, D. (1998). What Is Sport Education and How Does It Work? Journal of Physical Education, Recreation \& Dance, 69, 19-20. https://doi.org/10.1080/07303084.1998.10605528

Siedentop, D., Hastie, P. A., \& Hans Van Der Mas. (2011). Complete guide to sport education (2nd ed.). Human Kinetics Publishers.

Werner, P., Thorpe, R., \& Bunker, D. (1996). Teaching Games for Understanding: Evolution of a Model. Journal of Physical Education, Recreation \& Dance, 67(1), 28-33.

https://doi.org/10.1080/07303084.1996.10607176 